\title{
Financial Inclusion and Economic Development: An Analysis under the Brazilian Context
}

\author{
Clodoaldo Barbosa dos Santos ${ }^{1}$, Fabio Gallo Garcia1, Elmo Tambosi Filho ${ }^{2 *}$ \\ ${ }^{1}$ São Paulo School of Business Administration, São Paulo, Brazil \\ ${ }^{2}$ Production Engineering, The Federal University of Santa Catarina, São Paulo, Brazil \\ Email:*elmotf@hotmail.com
}

How to cite this paper: dos Santos, C. B. Garcia, F. G., \& Filho, E. T. (2021). Financial Inclusion and Economic Development: An Analysis under the Brazilian Context. Theoretical Economics Letters, 11, 1192-1209. https://doi.org/10.4236/tel.2021.116076

Received: October 30, 2021

Accepted: December 14, 2021

Published: December 17, 2021

Copyright (c) 2021 by author(s) and Scientific Research Publishing Inc. This work is licensed under the Creative Commons Attribution International License (CC BY 4.0).

http://creativecommons.org/licenses/by/4.0/

(c) (i) Open Access

\begin{abstract}
This paper investigates whether financial inclusion contributes to economic development in Brazil. The research was developed through descriptive statistical analysis, in addition to statistical regression and correlation, using secondary data collected from the Central Bank of Brazil (BACEN), United Nations Development Program (UNDP), and International Monetary Fund (IMF). The study period of the project comprised the years 2004 to 2017. As a result of the work, we found that there is a positive statistical correlation between financial inclusion and economic development in Brazil, demonstrated in the Pearson correlation matrix, indicated by the dependent variable of human development (HDI) and the independent variables, used as a proxy for financial inclusion, the number of bank branches and the currency liquidity index in Brazil. The values found were 0.899 and 0.938 respectively. Thus demonstrating that financial inclusion is an important drive for economic development, promoted through the access, use and quality of formal financial systems, and contributes to economic development in Brazil.
\end{abstract}

\section{Keywords}

Economic Development, Financial Inclusion, Brazil

\section{Introduction}

In 2015, according to a study carried out by the United Nations (UN), 736 million people still lived on less than US $\$ 1.90$ a day; an estimated 1.3 billion still live in multidimensional poverty, many lacking food, clean water and sanitation. In 2018, nearly 700 million workers lived in extreme or moderate poverty, on less than \$3.20 a day. Rapid growth in emerging economy countries such as China and India has lifted millions out of poverty, but progress has been uneven. 
In $2016,22 \%$ of global income was received by $1 \%$ of higher-income individuals, compared with $10 \%$ of world income received by $50 \%$ of lower-income individuals. These growing disparities require strong policies to empower low-income people and promote economic inclusion for all, regardless of gender, race or ethnicity (UNDP, 2020).

In Brazil, in 2017, only $1 \%$ of the Brazilian population, who have a formal bank account, used their cell phone to access the website of their banking institution and perform a money transfer, according to Demirgüç-Kunt (2017), even the country has almost $80 \%$ of its population in possession of a bank account at a financial institution.

One of the biggest success cases in the use of financial operation via cell phone is M-Pesa, which was launched in the African country of Kenya, in 2007 and operated by the company Vodafone, which allowed access to the formal financial system for more than 15 million people; expanding to other countries such as Egypt, India, Romania and Tanzania (Rojas-Suarez \& Amado, 2015).

Relatively new topic in the country, being inserted in the BACEN agenda from 2011, the present study seeks to enrich the current research literature through qualitative and quantitative analysis, as an exploratory study, analyzing the relationship of statistical significance between the economic development and financial inclusion.

\section{Financial Inclusion}

According to Ozili (2020), the financial inclusion movement started in the 1980s, after Robert Ayres made severe criticisms of the World Bank, in his book Banking on the poor: The World Bank and world poverty, where he argues that the tactics developed by the Bank World made the rich even richer and inequality increased.

According to the IBGE, in a statistical report released in 2018, the country has a population of about 209,469 million inhabitants and a demo figure density of around 24.4 inhabitants per $\mathrm{km}^{2}$. Large population and territories signal enormous challenges for the federal government, especially with regard to government support and infrastructure, aiming to adequately provide: education, health, employment, income and development.

This new definition by BACEN (2020) indicates financial citizenship as the exercise of rights and duties that allows citizens to manage their financial resources well. As a highlight of this new vision of financial inclusion, BACEN provides important numbers regarding financial inclusion in Brazil, such as service points, which demonstrates that out of every 05 municipalities, 02 still do not have at least one physical service point, which translates into a bank branch - a self-service terminal (ATM), a POS or a bank correspondent, with a downward trend. It thus demonstrates that in 2328 cities, the population still needs to move to another municipality to be able to carry out banking operations, such as withdrawals and bank loans. 
Thus, for the advent of this research project, its concept in a broader sense will be considered as financial inclusion, which includes not only access to a financial account at an institution, but also includes the use of services and products offered by the institutions banking.

\section{Benefits of Financial Inclusion}

According to Ozili (2020), financial inclusion through account ownership in a formal financial institution can be used for multiple purposes and offers many benefits to individuals, companies and the economy. The importance of financial inclusion and its diffusion across the globe revolves around the benefits achieved through the inclusion of the excluded poor population in the formal financial system. It can help reduce poverty and inequality by helping people to invest in the future, improve their consumption and better manage financial risks.

Congruent with this understanding, BACEN (2018) explains that this connection of financial inclusion with sustainable development permeates seven objectives, such as: SDG1, SDG2, SDG3, SDG5, SDG8, SDG9 and SDG10, as can be seen in Table 1.

According to the Corporate Social Responsibility report (CSR) in Harvard

Table 1. SDG'sx Inclusion financial

\begin{tabular}{|c|c|c|}
\hline Item & Related ODS & $\begin{array}{l}\text { Some Positive Effects of Expanding Access to Financial } \\
\text { Services }\end{array}$ \\
\hline SDG1 & $\begin{array}{l}\text { Eradication of } \\
\text { poverty }\end{array}$ & $\begin{array}{l}\text { Financial services related to credit and savings formation can } \\
\text { help households better absorb financial shocks, accumulate }\end{array}$ \\
\hline SDG2 & $\begin{array}{l}\text { Zero Hunger and } \\
\text { Sustainable } \\
\text { Agriculture }\end{array}$ & $\begin{array}{l}\text { assets and better manage medical care and invest in } \\
\text { education. }\end{array}$ \\
\hline SDG3 & $\begin{array}{l}\text { Health and } \\
\text { wellness }\end{array}$ & \\
\hline SDG5 & Gender equality & $\begin{array}{l}\text { Ensuring women's access to financial services, contributes to } \\
\text { women's empowerment, as gives them control over their } \\
\text { finances and helps to expand their economic power, which } \\
\text { may have an impact on their quality of life. }\end{array}$ \\
\hline SDG8 & $\begin{array}{l}\text { Decent work and } \\
\text { economic growth }\end{array}$ & $\begin{array}{l}\text { Expanding access to financial services increases the possibility } \\
\text { of mobilizing savings to finance productive ventures, } \\
\text { contributing to economic growth and job creation. }\end{array}$ \\
\hline SDG9 & $\begin{array}{l}\text { Industry, } \\
\text { Innovation and } \\
\text { Structure }\end{array}$ & $\begin{array}{l}\text { Access to credit, especially for small and female } \\
\text { entrepreneurs, can encourage the creation of companies and } \\
\text { the expansion of existing ones. }\end{array}$ \\
\hline SDG10 & $\begin{array}{l}\text { Reduction of } \\
\text { inequalities }\end{array}$ & $\begin{array}{l}\text { By helping to improve the lives of the poorest people, } \\
\text { financial inclusion contributes to reducing inequalities and } \\
\text { building a more inclusive society. }\end{array}$ \\
\hline
\end{tabular}

Source: Table prepared by the authors using BACEN data. 
University's Sutton and Jenkins initiative, financial services fundamentally benefit economic growth and development (Bisht \& Mishra, 2016).

\subsection{Barriers to Financial Inclusion}

Those excluded from formal financial systems can be classified into two groups of individuals that are those who are involuntarily excluded and those who prefer to be excluded from the financial system (Reports Abel, 2018, according to Allen et al., 2016).

\subsection{Innovation and Financial Inclusion}

In the year 2010, The G20 prepared a guide with policy and regulatory guidelines to encourage innovation within the financial industry, aiming to improve financial inclusion, by reducing costs and facilitating the transposition of barriers, which make it difficult to increase financial inclusion around the world. According to the G20 report, the result of the final report of the summit held in 2011, it lists nine basic principles that countries must follow in order to achieve innovative financial inclusion. The principles are listed below:

1) Leadership;

2) Diversity;

3) Innovation;

4) Protection;

5) Empowerment;

6) Cooperation;

7) Knowledge;

8) Proportionality;

9) Framework.

In appendix III of this work, the nine principles are listed in detail.

In the view of the authors, Yawe and Prabhu (2015), innovation in the financial area is one of the greatest existing drivers for financial inclusion, especially with regard to savings, means of payments, financial education and internet banking systems.

According to a report by the Global System for Mobile CommunicationsGSMA, entitled GSMA (2018), about 300 million people around the world used the internet for the first time in 2017, joining the global total of 3.54 billion people are already connected, meaning almost $50 \%$ of the world's population. The report also indicates that a large part of this population has only the cell phone as a means of accessing the internet. In this way, the report justifies, there is a boost in digital inclusion, especially in emerging countries.

In Brazil, in 2017, only $1 \%$ of the Brazilian population, who have a formal bank account, used their cell phone to access the website of their banking institution and perform a money transfer, according to Demirgüç-Kunt (2017), even the country has almost $80 \%$ of its population in possession of a bank account at a financial institution. 
One of the biggest success stories in the use of financial operation via cell phone is M-Pesa, launched in the African country of Kenya, in 2007, operated by the company Vodafone, which allowed access to the formal financial system for more than 15 million people, expanding to other countries such as Egypt, India, Romania and Tanzania (Rojas-Suarez \& Amado, 2015).

Vaslijeva and Lukanova (2016) teach that the internet and the internet banking service are becoming the main point of contact between financial institutions and customers, due to their simplicity, transparency and high convenience.

The second innovation item being implemented by BACEN, the PIX, acts specifically in the means of payments and bank transfers, seeking to reduce the cost of financial transactions. It enables transactions to be carried out instantly and cheaply, with availability twenty-four hours a day, including weekends and holidays. In practical terms, BACEN seeks to encourage, through this new payment platform, the emergence of new business models, a significant reduction in transaction costs and greater efficiency of financial institutions (BACEN, 2020).

\subsection{Financial Inclusion Indicators}

The insertion of the population formally excluded from the financial system has become an important goal for countries on all continents. In light of this, academia and social organizations become.

It is vital to measure and seek an understanding of how to improve the financial inclusion of countries and the population, in order to establish a comparison between nations and to determine the appropriate public policies for each region and/or country.

1) If the individual has a bank account at an institution formal financial;

2) If the individual saves or saves money in this institution and;

3) If the customer has carried out a formal credit operation (Demirgüç-Kunt, 2017).

The survey assesses the data over a period of twelve months, at each survey. Due to its extension and capillarity, this questionnaire has become an important tool to support research and help measure government policies and actions worldwide. A list of questions applied in the questionnaire will be available in ANNEX I of this work.

\subsection{Economic Development and Financial Inclusion in Brazil}

According to the IBGE, in a statistical report released in 2018, the country has a population of about 209,469 million inhabitants and a population density of around 24.4 inhabitants per $\mathrm{km} \mathrm{Z}$. Large population and territories signal enormous challenges for the federal government, especially with regard to government support and infrastructure, aiming to adequately provide: education, health, employment, income and development.

This new definition by BACEN (2020) indicates financial citizenship as the exercise of rights and duties that allows citizens to manage their financial re- 
sources well. As a highlight of this new vision of financial inclusion, BACEN provides important numbers regarding financial inclusion in Brazil, such as service points, which demonstrates that out of every 05 municipalities, 02 still do not have at least one physical service point, which translates as a bank branch - a self-service terminal (ATM), a POS or a banking correspondent, with a downward trend. It thus demonstrates that in 2,328 cities, the population still needs to move to another municipality to be able to carry out banking operations, such as withdrawals and bank loans.

Observing financial inclusion on the demand side, authors Jukan and Softić (2016) teach that it can be measured in each country according to the following requirements:

1) Formal possession of a bank account;

2) Formal savings at a financial institution;

3) Formal loans;

4) Credit card use;

5) Use for sending or receiving via the internet or mobile account.

In the view of BACEN, released by the RCF (2018), the percentage of the population covered by banks is $86.5 \%$. This difference is due to considering active and inactive accounts in its report, while FINDEX considers the use of the account in the last 12 months of the survey. A good part of these bank accounts participates in the "Bolsa Família" program, instituted by the federal government, as social income for the needy population (Table 2).

Checking the situation of financial inclusion on the supply side, that is, according to the numbers provided by financial institutions, the two indicators widely used by academia refer to the number of ATMs available, in addition to the number of bank branches. According to Aro-Gordon (2017), it is measured:

1) Number of ATMs (per 100,000 adults);

2) Number of bank branches (per 100,000 adults);

3) Number of bank accounts (per 1000 adults).

Between 2014 and 2018, the number of ATMs (per 100,000 adults) dropped from 118.08 to 104.79 , while the number of bank branches (per 100,000 adults) decreased from 21.26 to 18.99 , according to Table 3 .

BACEN indicates through the RCIF (2018), that transactions through non-

Table 2. Financial inclusion indicators demand side-year 2011/2017.

\begin{tabular}{cccc}
\hline & 2011 & 2014 & 2017 \\
\hline Formal account & $56 \%$ & $68 \%$ & $70 \%$ \\
Formal savings & $10 \%$ & $12 \%$ & $14 \%$ \\
Formal loan & $6 \%$ & $12 \%$ & $9 \%$ \\
Debit card & $41 \%$ & $59 \%$ & $59 \%$ \\
Mobile account usage & $\mathrm{AT}$ & $0 \%$ & $1 \%$ \\
\hline
\end{tabular}

Source: Table prepared by the authors from FINDEX and IMF data. 
presential means (home office banking, call centers, smartphones and PDA's) represented an increase of $20 \%$ between the years 2015 to 2016, and from 2016 to 2017 , in order of $21 \%$, representing $66 \%$ of all transactions carried out.

Regarding the measurement of economic development (Table 4), the human development index (HDI), which was planned by the United Nations Development Program (UNDP), in conjunction with researchers, the Indian Amartya Sene and the Pakistani Mahbub ul Haq, supported by three basic items: health, education and income (UNDP, 2018). In the view of Amartya and Mahbud, cited by Shaffer (2018), there is only developed when the benefits of growth serve to expand human capabilities.

In the last measurement carried out in 2018 (Table 5), Brazil was ranked $79^{\text {th }}$ in the world ranking, showing little evolution in the HDI compared to developed countries and indicating that there is still a long way to go, in a country with superlative numbers population and territorial area (Shown in Figure 1, the evolution of the HDI in Brazil, according to the numbers in Table 6).

\subsection{Banking System in Brazil}

Important to guarantee economic development, the stability of the financial system is a premise for financial inclusion to gain strength in the economy. According to Paula, Oreiro and Basílio (2013), the Brazilian banking sector is the largest and most complex in Latin America, mainly due to the Brazilian SBP payment system, which integrates all financial institutions with the BACEN in carrying out transfer operations between individuals or legal entities, ensuring low risk and stability.

Table 3. Financial inclusion indicators offer side-year 2011/2018.

\begin{tabular}{ccccccccc}
\hline & 2011 & 2012 & 2013 & 2014 & 2015 & 2016 & 2017 & 2018 \\
\hline (ATMs) & 116.44 & 115.5 & 118.59 & 118.08 & 115.11 & 112.22 & 107.96 & 104.79 \\
Bank agencies & 19.21 & 20.43 & 20.56 & 21.26 & 20.88 & 20.36 & 19.52 & 18.99 \\
\hline
\end{tabular}

Source: Table produced by the author from FINDEX and IMF data.

Table 4. Brazil-index Gini.

\begin{tabular}{ccccccccc}
\hline Years & 2011 & 2012 & 2013 & 2014 & 2015 & 2016 & 2017 & 2018 \\
\hline Brazil & 52.9 & 53.5 & 52.8 & 52.1 & 51.9 & 53.3 & 53.3 & 53.9 \\
\hline
\end{tabular}

Source: Prepared by the authors with data of the World Bank.

Table 5. Human development index-HDI-2010-2017.

\begin{tabular}{cccccccc}
\hline Years & rank & 2010 & 2012 & 2014 & 2015 & 2016 & 2017 \\
\hline Brazil & 79 & 0.727 & 0.736 & 0.752 & 0.757 & 0.758 & 0.759 \\
\hline
\end{tabular}

Source: elaborated by the author from UNDP data (2018). 


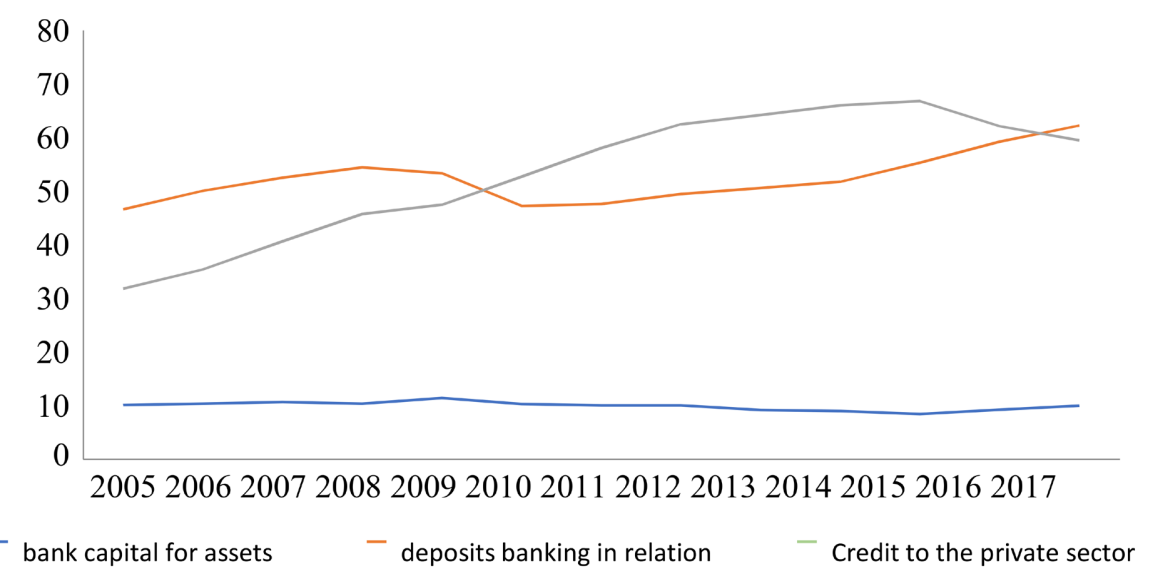

Source: Prepared by the authors with data from the World Bank and IMF.

Figure 1. Financial sector development-2010 to 2017.

According to the Brazilian Federation of Banks (FEBRABAN), in 2017, around BRL 3.1 trillion of credit operations were carried out in the country, with 153.7 million active consumers, where banks profited BRL 82.9 billion and together they have a net worth of $\mathrm{R} \$ 595.6$ billion.

\subsection{The Banking System and Inclusion Financial}

According to previous surveys carried out around the world, the financial system has a fundamental role in the development of financial inclusion, acting as a determining factor in this regard.

With regard to the supply of credit and deposits, the analysis was carried out with Brazilian data, which indicates a greater availability of credit for the economy. According to the FEBRABAN (2018), 10 in 2018 credit operations in the order of $\mathrm{R} \$ 3.3$ trillion were carried out, with a real increase of 5.5\% compared to the previous year. With regard to banking relationships, the report informs that there are approximately 158.4 million customers who have an active banking relationship.

\section{Research Methodology - Procedure and Data Analysis}

This research seeks to investigate the relationship between financial inclusion and economic development in Brazil, through statistical correlation and its causal relationship. Currently, there are not many studies dealing with the relationship of this theme in Brazil, and our research should contribute to the current bases in an original way, expanding the scientific knowledge base, as taught by Kothari (2004).

For the independent variables, we select six variables as a proxy for financial inclusion, according to a study by Van and Linh (2019) and Wang'oo (2008).

- Bank branch numbers;

- Number of ATM terminals;

- Credit provided to the sector private; 
- broad currency in \% to GDP;

- Number of existing bank accounts in the country;

- Bank credit deposited in \% to GDP.

The purpose of the tests is to verify the correlation between the independent variables and a dependent variable, validating which independent variables have statistical significance in their relationship, causing a percentage increase in the dependent variable.

\subsection{Data Collection Procedure}

For the research project, the procedure was carried out through the collection of secondary data, obtained from international bodies, such as the United Nations Development Program (UNDP), in addition to the IMF and the World Bank, for a period of 14 years, comprising the years 2004 to 2017, being considered as such, due to the project's deadline and budget. On the financial inclusion side, we used as a proxy 06 supply-side indicators, commonly used in academic research, as in the studies by Wang'oo (2008) and the authors Van and Linh (2019).

The data of the independent variables were selected from the websites and collected with the corresponding code of the World Bank, aiming to build a standardized document so that it can be consulted and improved in other academic studies on the subject in the future. The table with the selected variables indicating the detailed description of each one of them is listed in Table 6.

As an independent variable to estimate the relationship between economic development and financial inclusion, chosen as a basis for academic studies, the human development index (HDI), as a proxy, as already listed in this project.

\subsection{Linear Correlation Analysis}

The linear correlation analysis is performed using the Pearson correlation coefficient

Table 6. Independent variables of financial inclusion.

\begin{tabular}{|c|c|c|}
\hline Code & Variable & Definition \\
\hline GFDD. THERE.01 & Checking accounts & $\begin{array}{l}\text { Establishes the number of bank accounts per } 1000 \text { (adults), existing informal } \\
\text { financial institutions in the country. }\end{array}$ \\
\hline GFDD. THERE.02 & Bank agencies & Indicates the number of bank branches per 100,000 adults in the country. \\
\hline FB. ATM. TOTALP5 & Self-service terminals & Shows the number of ATMs in the country per 100,000 adults \\
\hline GFDD. SI.04 & $\begin{array}{l}\text { Deposits in institutions } \\
\text { financial }\end{array}$ & $\begin{array}{l}\text { Indicates the total sum of deposits made in cash, existing in financial } \\
\text { institutions in the country. }\end{array}$ \\
\hline FS.AST. PRV.GD. ZS & Loans to the private sector & $\begin{array}{l}\text { It means the provision of internal credit to the private sector, covering all loan } \\
\text { provided to companies, families and companies existing in the country in a } \\
\text { period of } 12 \text { months, }\end{array}$ \\
\hline $\begin{array}{l}\text { FM.LBL. BMNY.GD. } \\
\text { ZS }\end{array}$ & $\begin{array}{l}\text { Money in circulation at } \\
\text { economy }\end{array}$ & $\begin{array}{l}\text { Currency is wide in terms of percentage of GDP, what contemplate the total } \\
\text { coin physics in circulation at economy of parents. }\end{array}$ \\
\hline
\end{tabular}


(r), as indicated by Seward and Doane (2014), whose analysis is used to measure the relationship between two quantitative variables, having the numerical value of calculation between -1 and +1 , being dimensionless.

In Table 5, it was verified that the correlation of each independent variable and its degree of relationship with the dependent variable (HDI), with emphasis on the variables of credit to the private sector and large currency, with a significant factor between 0.9389 and 0.9402 , in that order.

Following the results and application of the model's polynomial equation, the ANOVA test was used to perform the analysis of variance. The observation interval of 14 years was used, involving the period from 2004 to 2017. For the multiple linear regression, the polynomial equation model as a function of $Y=f(x)$ will be used, where the standard format comprises a combination of variables independent and dependent.

The result of the first round of tests with regression analysis and Pearson's correlation is shown in Table 7.

In this model, the dependent variable $Y$ is, hypothetically, a function of $\mathrm{m}$ independent variables of $X_{1}, X_{2}, \ldots, X_{m}$, (Mcguigan, Moyer, \& Harris, 2016), presented in the form:

$$
Y_{i}=\beta_{0}+\beta X_{1}+\beta X_{2}+\beta X_{3}+\cdots+\beta X_{n}+\varepsilon
$$

The variables involved are listed. Next:

$Y=$ the dependent variable, used as the development index (economic development), collected from the UNDP database;

$X=$ independent variable that indicates financial inclusion, determined by various indicators, from the world bank and the IMF;

$X_{1}=$ represented by the number of ATMs and ATMs (per 100,000 adults);

$X_{2}=$ this variable represented by the total number of bank accounts (per 1000 adults). $X_{3}=$ variable represented by the total number of bank branches (per 100,000 adults). $X_{4}=$ variable represented by the amount of credit made to the private sector;

Table 7. Correlation of Pearson.

\begin{tabular}{|c|c|c|c|c|c|c|c|}
\hline & HDI & ATM & $\begin{array}{c}\text { Bank } \\
\text { accounts }\end{array}$ & Bank agencies & $\begin{array}{l}\text { Deposit } \\
\text { credits }\end{array}$ & $\begin{array}{l}\text { Credit to the } \\
\text { private sector }\end{array}$ & $\begin{array}{c}\text { Wide currency } \\
\% \text { GDP }\end{array}$ \\
\hline HDI & 1 & & & & & & \\
\hline ATM & 0.552675 & 1 & & & & & \\
\hline Bank accounts & 0.899224 & 0.641865 & 1 & & & & \\
\hline Bank agencies & 0.826281 & 0.572591 & 0.724674 & 1 & & & \\
\hline Deposit credit & 0.881946 & 0.823742 & 0.915942 & 0.842382 & 1 & & \\
\hline Credit to the private sector & 0.940246 & 0.749133 & 0.940298 & 0.838154 & 0.975515 & 1 & \\
\hline Broad currency \% GDP & 0.938894 & 0.448731 & 0.839663 & 0.686388 & 0.787789 & 0.886539 & 1 \\
\hline
\end{tabular}

Source: Prepared by author. 
$X_{5}=$ variable represented by available currency as a percentage of GDP;

$X_{6}=$ broad currency variable, the sum of money in circulation in the economy in relation to GDP;

$\beta_{0}=$ constant term;

$\beta_{1}=$ Coefficient to be estimated in the equation polynomial;

and $=$ error term, with margin $5 \%$.

Although it can be performed using matrix algebra, to estimate the alpha and beta coefficients, in order to facilitate the calculations, in the present study the computer software Excel and PAST4 were used. 0. Table 8 shows the summary of independent variables and dependent variables, indicating the frequency of analysis and the source.

\subsection{Analysis in Relationship Inclusion Financial Development}

To validate the relationship between financial inclusion and economic development, as a research object, a statistical relationship analysis was performed in terms of 01 null hypothesis, guided by academic studies already developed, in emerging economy countries, in the African continent and in Asia.

The model has significance and financial inclusion contributes to economic development in Brazil.

\section{Results and Discussion}

\subsection{Pearson Correlations and Regression Analyzes Multiple Linear}

As seen in the Pearson correlation section, the independent variable ATMs presented a moderate degree of correlation, with a value of $P=0.5526$. The independent variables bank accounts, bank branches and deposit credit showed a strong correlation with the dependent variable HDI, with the value of $P=$ $0.8992,0.8262$ and 0.8819 being found, in that order. The variables of credit to the private sector and large currency showed a very strong correlation, with $P=$ 0.940246 and $P=0.938894$, respectively.

Table 8. Group of dependent variables and independent variables.

\begin{tabular}{ccccc}
\hline Variable & Measurement & Description & Source & Frequency \\
\hline$Y$ & $\begin{array}{c}\text { Development } \\
\text { independent variable }\end{array}$ & financial inclusion & UNDP & Yearly \\
$X$ & independent variable & Development economic & WORLD BANK & Yearly \\
$X_{1}$ & independent variable & Development economic & WORLD BANK & Yearly \\
$X_{2}$ & independent variable & Development economic WORLD BANK & Yearly \\
$X_{3}$ & independent variable & Development economic WORLD BANK & Yearly \\
$X_{4}$ & independent variable & Development economic WORLD BANK & Yearly \\
$X_{5}$ & independent variable & Development economic WORLD BANK & Yearly \\
\hline
\end{tabular}

Source: Adapted from Sekantsi and Motelle (2018). 
In the first regression analysis performed, we found that the $\mathrm{RZ}=0.958355$, which validates the proposed model. The standard error is 0.006534 , which is below $5 \%$ of the confidence level proposed in the model. After the first round of regression, we found that the variables of credit in bank deposits and credit to the private sector obtained $P$ values of $62 \%$ and $17 \%$. Table 9 shows the result of the regression test:

In order to improve data quality, and seeking to identify which independent variables have statistical significance for the proposed model, a new round of regression was performed, removing the two variables that did not indicate a level of significance in the proposed model (credit in bank deposits and credit internal to the private sector).

Again, the RZ was very close to 1 , with a value of 0.958229 indicating the relevance of the data and the proposed model, and with a standard error of 0.005771 . These numbers validate the quality of the data (Table 10).

Thus, it is proven that in this model, the number of ATM machines and the number of bank accounts in the country, according to the proposed model, have no significance for financial inclusion, and consequently, in the independent variable HDI, thus not affecting economic development (Table 11).

\subsection{Residual Analysis}

Residual analysis is used in order to verify whether the type of statistical model has inadequacies, in addition to validating how well the proposed regression model fits the data used (Montegomery, Peck, \& Vinving, 2012: p. 130).

Table 9. Test result regression.

\begin{tabular}{ccccc}
\hline \multicolumn{2}{c}{ Regression statistics } & & \\
\hline Multiple r & 0.978956 & & \\
R-square & 0.958355 & & \\
Adjusted R-squared & 0.922660 & & & \\
Standard error & 0.006534 & & & \\
Comments & 14 & Standard error & Stat & P-value \\
\hline Coefficients & 0 & & & \\
Intersection & 0.0025 & 0.0005 & 5.0502 & $0 \%$ \\
ATM & 0.0002 & 0.0001 & 2.7937 & two $\%$ \\
Bank accounts & 0.0170 & 0.0031 & 5.5194 & $0 \%$ \\
Bank agencies & -0.0003 & 0.0006 & -0.5127 & $62 \%$ \\
Deposit credit & -0.0022 & 0.0015 & -1.5063 & $17 \%$ \\
Private sector credit & 0.0021 & 0.0006 & 3.6321 & $1 \%$ \\
Broad currency & & & & \\
\hline
\end{tabular}

Source: Prepared by author. 
Table 10. Re-Test Result regression ( $2^{\text {nd }}$ Round).

\begin{tabular}{|c|c|c|c|c|}
\hline \multicolumn{2}{|c|}{ Regression statistics } & & & \\
\hline Multiple r & 0.97889 & & & \\
\hline R-square & 0.95823 & & & \\
\hline Adjusted R-squared & 0.93966 & & & \\
\hline Standard error & 0.00577 & & & \\
\hline \multirow[t]{2}{*}{ Comments } & 14 & & & \\
\hline & Coefficients & Standard error & Stat $t$ & $P$-value \\
\hline Intersection & 0.47777 & 0.05617 & 8.50517 & $0 \%$ \\
\hline ATM & -0.00005 & 0.00050 & -0.09559 & $93 \%$ \\
\hline Bank accounts & 0.00006 & 0.00004 & 1.59044 & $15 \%$ \\
\hline Bank agencies & 0.00712 & 0.00266 & 2.67610 & $3 \%$ \\
\hline Broad currency \% GDP & 0.0112 & 0.00027 & 4.10285 & $0 \%$ \\
\hline
\end{tabular}

Source: Prepared by authors.

Table 11. Re-Test Result aggression ( $3^{\text {rd }}$ Round).

\begin{tabular}{ccccc}
\hline \multicolumn{5}{c}{ Regression statistics } \\
multiple r & 0.971617 & & & \\
R-square & 0.944040 & & & \\
adjusted R-squared & 0.933866 & & & \\
standard error & 0.006042 & & & \\
Comments & 14 & & & \\
& Coefficients & Standard error & P-value \\
\hline Intersection & 0.4485 & 0.03994 & 11.22997 & 0.0000002 \\
Bank agencies & 0.0087 & 0.00249 & 3.50559 & 0.0049217 \\
broad currency & 0.0014 & 0.00020 & 7.16686 & 0.0000183 \\
\hline
\end{tabular}

Source: Elaborated by the authors.

In Figure 2, we can see the independent variable number of bank branches in Brazil, where the normality of the data can be seen, demonstrated by the proximity of the main straight line distributed equidistantly.

In Figure 3, we have the Large Currency variable, also showing the normality of the data, explained by the equidistant distribution of the data on the main axis.

In both Figure 2 \& Figure 3, we can visually check that the variance of the residuals in the scatter plot is normally distributed around the central axis, as well as the variations above and below the straight line do not exceed the values between -0.01 and +0.015 . 


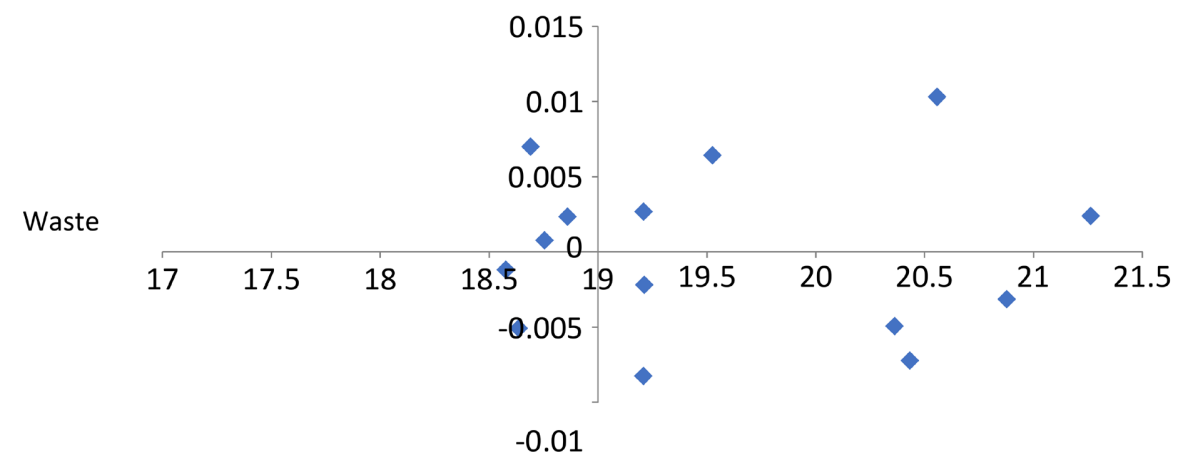

Source: Elaborated with data IMF 2018.

Figure 2. Independent variable residual analysis bank branch

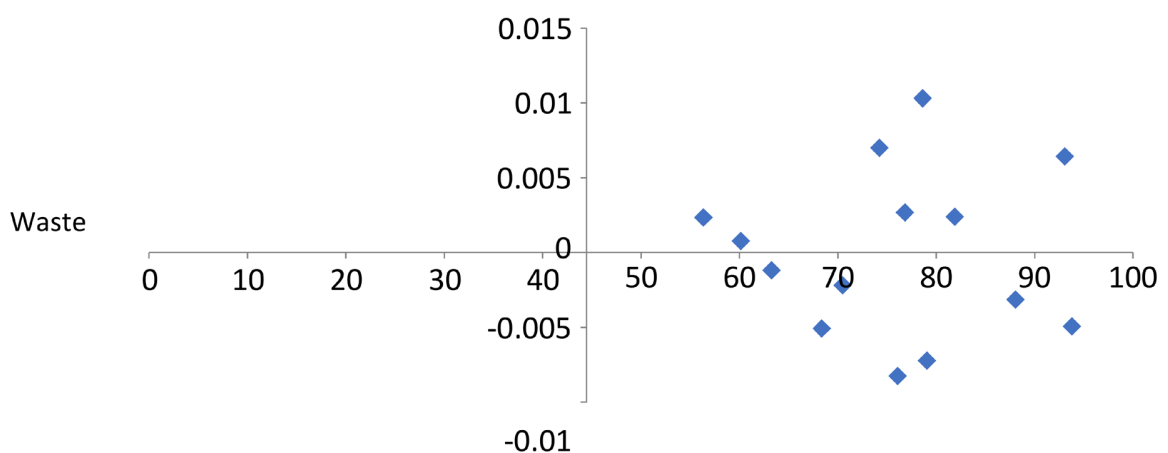

Source: Authors' data of the IMF 2018.

Figure 3. Independent Variable Residual Analysis large currency.

Ratifying this condition demonstrated in the Figures of the two independent variables, we performed a new regression round, explaining the residuals, through the Excel software, and realizing the difference between the predicted and realized residuals, finding a practically constant variation in absolute terms, remaining between 0.747130627 , from the first observation to 0.692301228 from the $14^{\text {th }}$ observation. This condition is shown in Table 12.

\subsection{Regression Analysis (Anova)}

After finding the two independent variables that have significance in the model, we proceeded with the analysis of variance (ANOVA) in order to verify the reliability of these variables in predicting the dependent variable.

From the result found in the third round of multiple linear regression and analysis of variance (ANOVA), of the independent variables, noting that they are statistically significant to the proposed model, we can assemble the model's polynomial equation. Using the general model proposed in the study, we arrive at the following equation:

$Y=0.4485+(0.0087 \times$ bank branches $)+(0.0014 \times$ broad currency $\% G D P)+\varepsilon(2)$

where $Y$ corresponds to the economic development index, using the human development index (HDI) proxy, "bank branches" corresponds to the total number 
of bank branches implemented in the country per 100,000 adults, and "large currency" corresponds to available capital in \% of the country's existing GDP, that is, monetary liquidity index. $\beta_{0}=0.4485, \beta_{1}=0.0087$ and $\beta_{2}=0.0014$, respectively.

This equation demonstrates that the country's economic development is related to financial inclusion, through the proxy number of bank branches and large currency. These two variables are shown in Figure 2, named scatter plot, demonstrating the positive relationship between financial inclusion and economic development in Brazil (Table 13).

Table 12. Analysis residual.

\begin{tabular}{cccc}
\hline Observation & Ypredicted & Waste & Waste difference \\
\hline 1 & 0.753565314 & 0.006434686 & 0.747130627 \\
two & 0.761930313 & -0.004930313 & 0.766860626 \\
3 & 0.758127470 & -0.003127470 & 0.761254941 \\
4 & 0.752595995 & 0.002404005 & 0.750191989 \\
5 & 0.741692792 & 0.010307208 & 0.731385583 \\
6 & 0.741209426 & -0.007209426 & 0.748418853 \\
7 & 0.727311760 & 0.002688240 & 0.724623520 \\
8 & 0.719007507 & 0.006992493 & 0.712015014 \\
9 & 0.726242388 & -0.008242388 & 0.734484776 \\
10 & 0.718191207 & -0.002191207 & 0.720382413 \\
11 & 0.710070735 & -0.005070735 & 0.715141470 \\
12 & 0.702178244 & -0.001178244 & 0.703356489 \\
13 & 0.699226235 & 0.000773765 & 0.698452470 \\
14 & 0.694650614 & 0.002349386 & 0.692301228 \\
\hline
\end{tabular}

Source: Authors' data of the IMF 2018.

Table 13. Analysis of variance THE NEW.

\begin{tabular}{ccccccc}
\hline Group & Score & Sum & Average & Variance & & \\
\hline HDI & 14 & 10.206 & 0.729 & 0.000552 & & \\
Agencies banks & 14 & 274.1473 & 19.58195 & 0.8546883 & & \\
Broad currency \% & & 1060.2654 & & 130,70882 & & \\
GDP & 14 & 1 & 75.7332435 & two & & \\
\hline Source of variation & SQ & gl & MQ & F & $P$-value & F critical \\
\hline & & & & & $2.71238 \mathrm{E}-$ & 3.23809613 \\
Between groups & $42,625.51$ & two & $21,312.7554$ & 485.9858 & 28 & 5 \\
within groups & 1710.333 & 39 & 43.8546875 & & & \\
Total & $44,335.84$ & 41 & & & & \\
\hline
\end{tabular}

Source: Prepared by authors. 


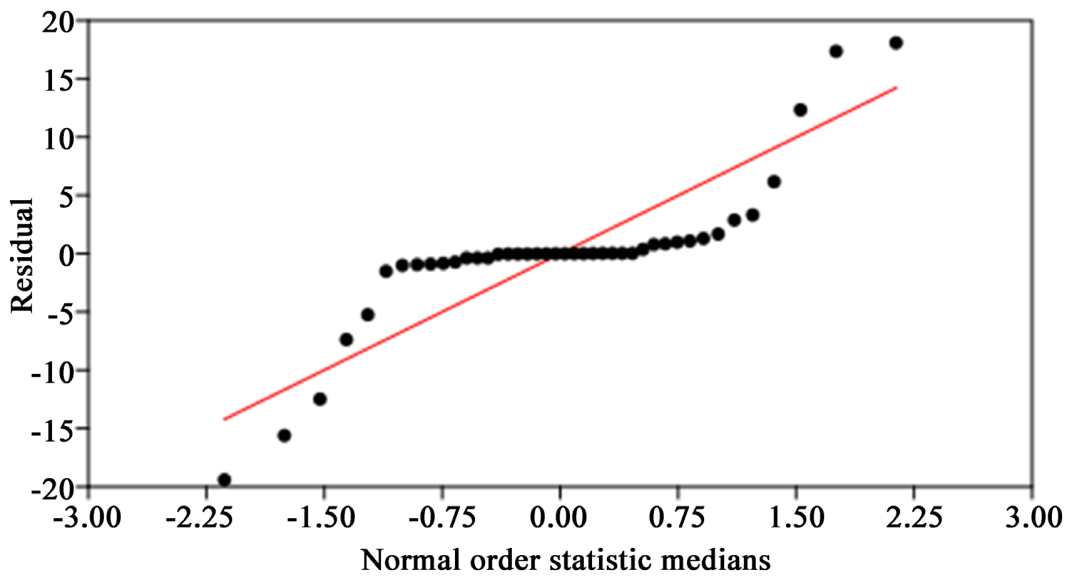

Source: Prepared by the authors.

Figure 4. Scatter plot of regression variables.

This equation demonstrates that the country's economic development is related to financial inclusion, through the proxy number of bank branches and ample currency. These two variables are shown in Figure 4, named scatter plot, demonstrating the positive relationship between financial inclusion and economic development in Brazil.

In relation to the main objective of the research, it was verified that the model does not have nullity. In other words, he demonstrated a direct relationship between financial inclusion and development, through the relationships between the dependent variable and the independent variables.

\section{Conclusion and Recommendations}

From the analysis carried out, Pearson correlation and multiple linear regression, we verified that economic development has a strong relationship with financial inclusion, through the proxy of the number of bank branches and large-currency liquidity in Brazil. The RZ value of the proposed model presented $\mathrm{RZ}=0.944040$, meaning that $94.40 \%$ of the research objective can be explained. The $P$ value found was 0.0000023 , demonstrating the high significance of the model.

The number of bank branches per 100,000 adults and broad currency as a \% of GDP has a strong statistical relationship with the economic development proxy (HDI), with a 95\% confidence level. Statistically, these variables had a $P$ of 0.00492166 and 0.0001829 , respectively.

Confirming the initial objective of the work, to identify the level of relationship between the phenomenon of financial inclusion and economic development, it was concluded that for each $1 \%$ increase in the number of bank branches in the country, economic development will increase by around 0 $0.00874 \%$, while increasing the monetary liquidity index variable by $1 \%$, the level of economic development will proportionally increase in the order of $0.00144 \%$.

The analysis above shows his new definition by BACEN (2020) indicates fi- 
nancial citizenship as the exercise of rights and duties that allows citizens to manage their financial resources well. As a highlight of this new vision of financial inclusion, BACEN provides important numbers regarding financial inclusion in Brazil, such as service points, which demonstrates that out of every 05 municipalities, 02 still do not have at least one physical service point, which translates into a bank branch-a self-service terminal (ATM), a POS or a bank correspondent, with a downward trend. It thus demonstrates that in 2328 cities, the population still needs to move to another municipality to be able to carry out banking operations, such as withdrawals and bank loans.

\section{Conflicts of Interest}

The authors declare no conflicts of interest regarding the publication of this paper.

\section{References}

Abel, B. B. (2018). Financial Inclusion in Burundi: The Determinants of Loan-Taking Motivation in Semi-Rural Areas. International Journal of Organizational Innovation, 11, 1-14.

Allen, F. et al. (2016). The Foundations of Financial Inclusion: Understanding Ownership and Use of Formal Accounts. Journal of Financial Intermediation, 27, 1-30. https://doi.org/10.1016/j.jfi.2015.12.003

Aro-Gordon, S. (2017). Implementation of Financial Inclusion Strategy in Nigeria. SDMIMD Journal of Management, 8, 27-43. https://doi.org/10.18311/sdmimd/2017/17876

BACEN Brazilian Central Bank (2018). RCIF Financial Inclusion Report. No. 1, Central Bank of Brazil.

BACEN Brazilian Central Bank (2020). Financial Inclusion Report. No. 3, Central Bank of Brazil. https://doi.org/10.1596/33629

Bisht, S. S., \& Mishra, V. (2016). ICT-Driven Financial Inclusion Initiatives for Poor Urban Development in a Developing Economy: Implications for Public Policy. Behavior \& Information Technology, 35, 817-832. https://doi.org/10.1080/0144929X.2016.1183711

Demirgüç-Kunt, A., Klapper, L., Singer, D., Ansar, S., \& Hess, J. (2018). The Global Findex Database 2017: Measuring Financial Inclusion and the Fintech Revolution. World Bank Group. https://doi.org/10.1596/978-1-4648-1259-0

Doane, D. P., \& Seward, L. E. (2014). Statistics Applications in Business and Economics (4th ed.). McGraw Hill.

Jukan, M. K., \& Softić, A. (2016). Comparative Analysis of Financial Inclusion in Developing Regions around the World. Economic Review: Journal of Economics \& Business, 14, 56-65.

Kothari, C. R. (2004). Research Methodology Methods \& Techniques. New Age International Publisher.

Mcguigan, J. R., Moyer, R. C., \& Harris, F. H. B. (2016). Business Economics: Applications, Strategies and Tactics. Cengage Learning.

Montegomery, D. C., Peck, E. A., \& Vinving, G. G. (2012). Introduction Regressions Analy- 
sis (Vol. 821). John Wiley \& Sons.

Ozili, P. K. (2020). Optimal Financial Inclusion. SSRN Electronic Journal. https://doi.org/10.1108/S1569-376720200000021014

Paula, L. F., Oreiro, J. L., \& Basilio, F. A. C. (2013). Structure of the Banking Sector and the Recent Credit Expansion Cycle: The Role of Federal Public Banks. New Economy, 23, 473-520. https://doi.org/10.1590/S0103-63512013000300001

Rojas-Suarez, L., \& Amado, M. (2015). Understanding Latin America's Financial Inclusion Gap. Earth, 367, 1-45. https://doi.org/10.2139/ssrn.2458138

Shaffer, P. (2018). New Thinking on Poverty: Implications for Globalisation and Poverty Reduction Strategies. DESA Working Paper No. 65, United Nations.

United Nations Development Program. Human Development Indices and Indicators: 2020 Statistical Update.

United Nations Development Programme. Human Development Indices and Indicators 2018 Statistical Update.

Van, D. T. T., \& Linh, N. H. (2019). The Impacts of Financial Inclusion on Economic Development: Cases in Asian-Pacific Countries. Comparative Economic Research, 22, 7-16. https://doi.org/10.2478/cer-2019-0001

Vaslijeva, T., \& Lukanova, K. (2016). Commercial Banks and Fintech Companies in the Digital Transformation. Journal Business Management, 11, 45-34.

Wang'oo, E. W. (2008). The Relationship between Financial Inclusion and Economic Development in Kenya. University of Nairobi.

Yawe, B. L., \& Prabhu, J. (2015). Innovation and Financial Inclusion: A Review of the Literature. Journal of Payments Strategy \& Systems, 9, 215-228.

RCIF (2018). Financial Inclusion Report. No. 3, Central Bank of Brazil. https://doi.org/10.1596/33629

GSMA (2018). The State of Mobile Internet Connectivity Report 2018. Mobile for Development. https://www.gsma.com/mobilefordevelopment

FEBRABAN (FederaçãoBrasileira de Bancos) (2018). Pesquisa FEBRABAN de TecnologiaBancária 2018. http://www.ciab.org.br/publicacoes/\#pesquisa-febraban 